\title{
Intergenerational living: An intercultural comparison
}

This article explores the factors behind young adults living in shared households with their parents for an extended period of time. We were interested in finding out if they think the state should implement regulatory measures to help them become independent. Our hypothesis is that the young and old living together as an extended family is not an indicator of intergenerational symbiosis and solidarity, but rather a reflection of wider social and cultural processes regulating the life of society as a whole and the lives of individuals. The study was carried out in three different cultural environments: Slovenia, Serbia and Japan. The study showed that, despite the fact that they get along relatively well, young people living in a shared household with their parents still want to "go it alone" and they expect greater help from the state, through regulatory measures and fair distribution of social assistance between the "young" and the "old" generations, to create social and housing policies that are fairer and friendlier to young families. This would reduce the pressure on the family and the potential for conflict within it, as well as the potential for conflict between the state and the family. Japanese participants expressed the highest level of agreement with this, whereas Serbs expressed the lowest. In terms of sources of financing for buying a home, the Slovenian participants express the highest level of agreement when it comes to financing through loans, whereas Serbian and Japanese participants also count on their own financial resources, which we interpret as a typical social phenomenon of the intergenerational transfer of title or a demonstration of high expectations of financial assistance from relatives. However, we established that the significant intercultural difference in the monthly use of funds for housing rental or purchase can be indicative of the participants' varying expectations and opportunities to enter the home-ownership world or an independent household.

Keywords: young people, housing, intergenerational living, expectations, Slovenia, Serbia, Japan 


\section{Introduction}

Economic, social, cultural, political and demographic changes have a significant impact on traditional family, social, structural and intergenerational relationships (Ramovš, 2013). These can be seen in the currently increasing problem of shared households or the extended time that young people, young families and their parents live communally. The issue is becoming a more and more common topic at the political level as well as in scholarship. When the children do move out and into what type of home and living arrangements depends on many personal and social circumstances. According to Srna Mandič (2007), these factors are, on the one hand, individual and extend to the micro-level, at which one's wishes, choices and resources are of key importance; on the other hand, these factors are structural and, at the macro-level, define a multitude of opportunities and obstacles that individuals face in their choices in a given environment. Structural factors are characteristics of the environment and explain why individuals of the same society follow similar home-leaving patterns and why these patterns differ by country. The latter are relatively well-researched (Mandič, 2009; Kuhar, 2012; Emmons \& Noeth, 2014; Bratina Jurkovič, 2014). On the other hand, growing up, which predominantly used to be a standardised and predictable process, has turned into an individual project in today's conditions - one that is each person's sole responsibility. However, this does not mean that the role of the state and society at large is not important in establishing the conditions for successfully transitioning young people to adulthood (Lavrič, 2011). The aim of this study was to find out whether young people believe that the state should take regulatory measures to help them become independent. We explored the reasons young people live in a shared household with their parents and, in this context, analysed their wishes, purpose, manner and expectations after moving out and "going it alone". Our hypothesis is that the young and old living together as an extended family is not an indicator of intergenerational symbiosis and solidarity, but rather a reflection of wider social and cultural processes regulating the life of society as a whole and the lives of individuals. Alan Walker (2006) even claims that policy-makers do not understand the core meaning of intergenerational solidarity but regard it as only a funding/ spending relationship. He believes that thinking and policies that follow the assumption that social investments and education are mainly for young people stem from the old paradigm of a three-generational society. This can pose a risk of intergenerational conflict because, by doing so, the public finance distributors of the welfare state give special treatment to certain social groups. Both the young and the old generation have a number of needs that, particularly in times of reduced economic growth (or recession), will be increasingly difficult to satisfy from the resources of the welfare state. According to Ksenija
Ramovš (2013), this can lead to conflict between the two. In this context, we were interested in learning about young people's level of satisfaction with their current living conditions in a shared household. Vincent R. Waldron et al. (2005) write about the trend of the socialisation of the older generation in new environments, but at the same time they call attention to their distinct attachment to their home surroundings. The family environment is associated with a common history, close intergenerational relationships and family tradition. It reflects symbiosis and care for older relatives as a natural continuation of tradition and reciprocal intergenerational support in everyday life (Jolanki, 2015). We wanted to know if mutual living dependence is also conditional upon this attachment.

As Miran Lavrič and Rudi Klanjšek (2013) conclude, the risk of poverty among young people not living with their parents is significantly higher compared to those staying at home, mainly in countries with a liberal regime of transitions of young people into their own households and the early home-leaving associated with it. In countries with a sub-protective (Mediterranean) regime, such differences are barely visible. Numerous researchers (Aassve et al., 2006) conclude that this can only be explained by cultural factors. Our study was carried out in three different cultural environments: Slovenia, Serbia and Japan. The selection criteria were the countries' varied levels of economic development and strategic position (Slovenia as a part of the EU, Serbia as a part of the former Socialist Federal Republic of Yugoslavia and Japan as a highly technologically developed Asian country). The study was conducted with 1,006 Slovenian, 385 Serbian and 264 Japanese participants.

\section{Structural and individual factors of living together}

The study was inspired by the results of various studies showing, among other things, that almost half of young Europeans 15 to 30 live with their parents (Eurostat, 2012). Of these, $26 \%$ indicate that their reason for not moving out is because there are not enough affordable housing options, $11 \%$ indicate that they are living in their parents' household due to home advantages without needing to take responsibility for them and $10 \%$ say that they are living at home because they will eventually marry or move in with their partner. Only $3 \%$ of young people up to 30 are living at home because they are supporting their parents financially. In terms of the number of young people (25-34 years) living with their parents, Slovenia is at the very top. According to Eurostat (2012), 43.5\% of young people in Slovenia in this age group are still living at home. Thus, Slovenia is one of the top countries when it comes to the length of time young adults live with their parents. Ac- 
cording to the European Union Labour Force Survey (2013), which offers comparisons between EU member states, Slovenia is second in Europe, right behind Slovakia (even ahead of Italy) when it comes to the duration of intergenerational living of parents and their children. Studies show that these days young people in Europe reach the turning points of growing up, such as a steady job, financial stability, housing independence and a stable partnership, later in life (Ule \& Kuhar, 2003). Delaying one's move away from one's primary family is characteristic of all of Europe (Biggart et al., 2004; Holdsworth \& Morgan, 2006; Pompe \& Temeljotov Salaj, 2014). In their study, Mirjana Ule and Metka Kuhar (2003) also establish that one of the most common reasons respondents indicate for continuing to live with their parents is their inability to find independent housing. Kuhar (2013) highlights the following key reasons for extended intergenerational living in Slovenia: the small amount of affordable housing; the poorly-developed labour market and culturally-specific practice associated with broader factors of a structural or institutional nature, particularly with the availability of state aid in relation to family assistance. On the other hand, the growing abundance of recent decades has meant that, for the first time in history, a large part of the European population is transferring its relatively large amount of property to their children's generation (Brandt et al., 2008). All this affects the current phenomenon of young families living with their parents for an extended period. Most authors, however, believe that the family should be viewed from a complementary point of view, meaning that if the state provides functional assistance to families, it lightens their burden (Ramovš, 2013). According to Walter Korpi (2000), this reduces pressure on the family and thereby the potential for conflict within it, as well as the potential for conflict between the state and the family.

The transition from the parental home to an independent home can be explored in various contexts, but we were mainly interested in this issue in terms of one's housing career. We were therefore faced with the question of which type of housing one's first independent home can be. In some countries, renting plays an important role, for instance in the Netherlands and Germany (Mulder, 2006), whereas in south European countries building one's own home, often with the help of relatives, plays an important role in acquiring independent housing (Allen et al., 2004). According to Mandič (2007), the latter is also true for Slovenia. Christian Mulder (2006) believes the greatest obstacles to accessible housing for young people are the high percentage of owner-occupied housing, poor credit policy and high property prices. In countries in transition, the extended period of living with parents can even be interpreted as "collateral damage" of the housing reform that radically reduced the public rental sector, whereas expectations of privacy in this respect do not seem to be realistic (Mandič, 2007; Mandič \&
Filipovič Hrast, 2015). Parents are supposed to be the ones trying to mitigate the consequences of the disintegration of the former universal welfare state (Kovacheva, 2006). However, as Ule and Kuhar (2003) point out, young people on average enjoy a fair degree of autonomy at home with their parents and this extended period of living with parents can thus, at least to a certain extent, be interpreted as a lifestyle choice related to the comfort of "hotel mama". Following our hypothesis that the young and old living together as an extended family is not in itself an indicator of intergenerational symbiosis and solidarity, we were interested in the individual reasons for living together and the factors behind it. We wanted to know how young people perceive intergenerational living and what their expectations are in terms of finding housing. According to Ronald Goetegeluk et al. (1992), a household opts for another home if it offers more advantages than disadvantages compared to the previous home. In this context, the connection between employment and housing and the consequent housing mobility is also important. According to Mandic (2009), housing mobility generally carries a positive connotation, because greater mobility is supposed to reflect the fact that more households are moving into homes that are more appropriate for them. In a developed economy, numerous households even decide to look for housing and employment opportunities, choosing the one that offers the best possible combination of both (van Ommerren et al., 2000; Yau, 2015). Statistical data for Slovenia show a very low level of housing mobility. We associate this with limited access to sources of housing, particularly rentals. Other important factors include the pronounced prevalence of owner-occupied housing, the highly developed practice of self-sufficiency, dispersed land ownership and the very liberal urban planning system in the past.

When it comes to Japan, Ge Jian and Hokao Kazunori (2004) have established the effect of regional characteristics and personal housing preferences on the evaluation of housing environments in local towns. The authors explored the factors affecting the way of life in Japanese cities in terms of property user satisfaction, user preferences and the available choices in purchasing property (Jian \& Kazunori, 2006). In terms of preferences when looking for a place to live, their results show three main groups of participants, namely those who prefer an urban over a natural environment, enjoy a working environment (job) and are principally prepared to invest in the standard of the home's immediate vicinity, followed by participants who prefer a non-urban environment, favour everyday life over work and are principally prepared to invest in their home, whereas the third group of participants is in between the two and favours social activities and interpersonal relationships when choosing a place to live. One typical feature of Japan is that the share of people who have never been married has risen dramatically since 1970 (in adults between 30 and 34 from 11.6\% to $42.9 \%$ 
for men and from $7.2 \%$ to $26.6 \%$ for women). The age of first marriage has also risen significantly in this period, namely from 27.5 to 30.8 years for men and from 24.7 to 28.6 for women (the National Institute of Population and Social Security Research, 2008). Similar trends can be detected in Europe as well, although they are not as pronounced. Researchers associate later marriage and the larger percentage of unmarried people in European countries with different (changed) living conditions (Goldscheider, 1997; Bianchi \& Casper, 2000). But this, as Setsuya Fukuda (2007) points out, is not typical of Japan. Numerous scholars are striving to identify the reasons young Japanese stay at home longer (Takahashi \& Voss, 2000; Takada, 2004; Fukuda, 2007; Suzuki 2007) and what demographic consequences this has (Raymo, 2003; Raymo \& Ono, 2004; Suzuki, 2007). They discovered that, in Japan, women typically marry at a younger age than men, but it seems to be the only country where men leave their parents' homes earlier. They cite education and employment as some of the reasons for this. Finances are indicated as the main obstacle to young people becoming independent. Establishing a new household is very expensive in Japan. According to Misa Izahura (2014), the reason for later home-leaving is mainly related to the economic recession and the wider neoliberal globalisation. Women's age of first marriage has increased from around 20 to around 30, which is also the age they decide to buy a home. They see ownership mainly as a useful value and a sense of security in old age.

Smiljka Tomanović and Suzana Ignjatović (2006) write that, in Serbia, young people typically associate the transition to their own household with starting their own family rather than with an independent lifestyle. According to them, almost one fifth of young respondents cite marriage (or pregnancy) as the main condition for moving in with one's partner and, as a result, leaving home and establishing one's own household. Other prerequisites for becoming independent from one's parents include: a good income, a job and the accessibility of independent housing. For young people in Serbia, there is no discrepancy between the normative and the practical level of the transition to adulthood. Starting a family is considered to be a "strategy" in the transition to adulthood. According to Tomanović and Ignjatović (2006), young people in Serbia do not see moving out as the end of their parent-dependent lifestyle but as a prerequisite for their transition to adulthood. This sample is in contrast to the European trend, where independence from one's parents or moving out does not necessarily mean starting one's own family (Heath, 1999).

Joachim Vogel (2002) concluded empirically that societies with different types of welfare constellations also differ in the age when young people leave their parents' homes. $\mathrm{He}$ discovered that, in societies with a characteristically poorly functioning labour market (a difficult entry of young people into the labour market) and weak risk-mitigating measures of the welfare state (low social security expenditure), young people leave their parents' homes the latest. According to Nada Stropnik and Milivoja Šircelj (2008), young people's housing and employment careers are related. Thus, young people stay with their parents until their employment career allows them to become economically independent in the sense that they can take out a housing loan and thereby attain the predominant ownership status. How a joint family budget affects when young families leave their shared household with their parents is difficult to predict (Hartley, 1993). Many countries are faced with demographic changes, such as a rapidly ageing population and a falling fertility rate. Stropnik and Šircelj (2008) thus highlight that, among other things, moving out of one's parents' home (household) has an important effect on fertility. According to Lavrič (2011), 50\% of young people in Slovenia living in an independent household have at least one child at the age of 29 , compared to only a good $15 \%$ of young people who live with their parents. It seems that the state, instead of offering young people low-cost housing, forces them into ownership that they cannot afford. This, in turn, prevents them from becoming independent and having children.

\section{Methods and participants}

The research method used was based on a questionnaire (Walonic, 2007) drawn up as part of a larger research project. It was carried out in various cultural environments and its main goal was to determine the factors that have a decisive impact on potential future property rights holders when deciding on a property purchase (Grum, 2014; Grum \& Kobal Grum, 2015). Out of the three main types of questions (Keats, 2000) - that is, open-ended questions (giving the participant complete freedom to answer), multiple-choice questions (the participant chooses the most appropriate answer) and questions with answers by type (the Likert scale) - the last two types were used. The participants expressed their opinions on a five-point Likert scale ( 1 - completely unimportant, 5 -very important). The data was processed using SPSS statistical software. The statistical analysis encompasses the factor analysis of the questionnaire, the reliability analysis of the questionnaire (Cronbach's alpha), descriptive statistics and variance analysis (Grum \& Temeljotov Salaj, 2010b). The section of the questionnaire measuring demographic features includes 34 variables. We extracted eight factors that account for over $60 \%$ of the variance (Grum \& Temeljotov Salaj, 2010a). The KaiserMeyer-Olkin measure of sampling adequacy is 0.759 , which means that the measured variables are a good psychometric match (Fulgosi, 1984). The statistically significant Bartlett's test $(\mathrm{BT}=2,178.119)$ shows that the extracted factors can be interpreted (Fulgosi, 1984). 
Table 1: The structure of the participants in terms of demographic features.

\begin{tabular}{|c|c|c|c|c|c|c|}
\hline Cultural origin & Slovenians & Serbs & Japanese & & & \\
\hline Slovenia, Japan, Serbia & Number & Percentage & Number & Percentage & Number & Percentage \\
\hline \multicolumn{7}{|l|}{ Gender } \\
\hline Women & 623 & 61.93 & 276 & 71.88 & 90 & 34.09 \\
\hline Men & 383 & 38.07 & 108 & 28.13 & 174 & 65.91 \\
\hline Total & 1,006 & 100.00 & 384 & 100.00 & 264 & 100.00 \\
\hline \multicolumn{7}{|l|}{ Age } \\
\hline 20 to 29 & 490 & 48.71 & 222 & 57.81 & 114 & 43.18 \\
\hline 30 to 40 & 516 & 51.29 & 162 & 42.19 & 150 & 56.82 \\
\hline Total & 1,006 & 100.00 & 384 & 100.00 & 264 & 100.00 \\
\hline \multicolumn{7}{|l|}{ Family status } \\
\hline Single & 264 & 26.53 & 178 & 46.35 & 168 & 65.12 \\
\hline $\begin{array}{l}\text { In a relationship or mar- } \\
\text { ried }\end{array}$ & 731 & 73.47 & 206 & 53.65 & 90 & 34.88 \\
\hline Total & 995 & 100.00 & 384 & 100.00 & 258 & 100.00 \\
\hline \multicolumn{7}{|l|}{ Where do you live (location)? } \\
\hline In the city centre & 316 & 31.76 & 208 & 54.17 & 114 & 44.19 \\
\hline On the outskirts of a city & 321 & 32.26 & 144 & 37.50 & 132 & 51.16 \\
\hline In a clustered village & 234 & 23.52 & 18 & 4.69 & 6 & 2.33 \\
\hline In a dispersed village & 116 & 11.66 & 0 & 0.00 & 0 & 0.00 \\
\hline Elsewhere & 8 & 0.80 & 14 & 3.65 & 6 & 2.33 \\
\hline Total & 995 & 100.00 & 384 & 100.00 & 258 & 100.00 \\
\hline \multicolumn{7}{|l|}{ I am currently living } \\
\hline $\begin{array}{l}\text { In private or co-owned } \\
\text { housing }\end{array}$ & 531 & 53.64 & 258 & 67.19 & 72 & 27.91 \\
\hline In market rental housing & 99 & 10.00 & 82 & 21.35 & 96 & 37.21 \\
\hline In low-rent housing & 27 & 2.73 & 0 & 0.00 & 24 & 9.30 \\
\hline With my parents & 269 & 27.17 & 24 & 6.25 & 54 & 20.93 \\
\hline Other & 64 & 6.46 & 20 & 5.21 & 12 & 4.65 \\
\hline Total & 990 & 100.00 & 384 & 100.00 & 258 & 100.00 \\
\hline \multicolumn{7}{|c|}{ Monthly housing expenditure: } \\
\hline Nothing & 450 & 45.73 & 278 & 72.40 & 60 & 23.26 \\
\hline $\begin{array}{l}\text { Less than } 30 \% \text { of my } \\
\text { income }\end{array}$ & 216 & 21.95 & 38 & 9.90 & 150 & 58.14 \\
\hline Around $30 \%$ of my income & 149 & 15.14 & 34 & 8.85 & 24 & 9.30 \\
\hline $\begin{array}{l}\text { More than } 30 \% \text { of my } \\
\text { income }\end{array}$ & 129 & 13.11 & 32 & 8.33 & 24 & 9.30 \\
\hline Almost all of my income & 40 & 4.07 & 2 & 0.52 & 0 & 0.00 \\
\hline Total & 984 & 100.00 & 384 & 100.00 & 258 & 100.00 \\
\hline \multicolumn{7}{|c|}{ Satisfaction with living conditions } \\
\hline Very unsatisfied & 76 & 7.74 & 55 & 14.32 & 30 & 11.63 \\
\hline Unsatisfied & 105 & 10.69 & 38 & 9.90 & 24 & 9.30 \\
\hline Reasonably satisfied & 220 & 22.40 & 46 & 11.98 & 48 & 18.60 \\
\hline Satisfied & 281 & 28.62 & 76 & 19.79 & 90 & 34.88 \\
\hline Very satisfied & 300 & 30.55 & 92 & 23.96 & 66 & 25.58 \\
\hline Totally satisfied & 982 & 100.00 & 384 & 100.00 & 258 & 100.00 \\
\hline
\end{tabular}


The study was conducted with 1,006 Slovenian, 385 Serbian and 264 Japanese participants between 20 and 40, selected by gender, education, social and economic status, marital or family status, living environment and cultural identity. In the first phase, data was collected via the Internet. Unlike Slovenian participants, the Japanese and Serbian participants were deeply suspicious of participating in online surveys. As a result, snowball sampling was used in the second phase of data collection (Lobe, 2006). In using this type of sampling, personal acquaintances are recruited to build a pattern of the group studied. A smaller sample of people is chosen to complete the questionnaire and they, in turn, ask their acquaintances to do the same (Klinc et al., 2010). Each new respondent is supposed to recruit a few other respondents. The main advantage of this type of sampling is the rapid collection of a sample that is, however, solely dependent on the initial selection of the population. That is also one of its disadvantages, as control over the sample is lost after the initial selection. Another disadvantage is its dependency on the individual's horizontal and particularly vertical networking. Furthermore, the problem in acquiring Japanese participants was increased by the fact that in Japan it is not allowed to distribute questionnaires in public spaces (without the approval of a special ethics committee). This resulted in the varying sample sizes of the different cultures. Data was collected between November 2013 and May 2014. The structure of the participants in terms of their demographic features is shown in Table 1.

The table shows that, unlike in Slovenia and Serbia, the majority of Japanese participants are men (65.91\%). Findings concerning the Japanese cultural environment (Forrest et al., 2003; Hirayama, 2008) suggest that it is not surprising to encounter differences between the sexes in the home-ownership rate, because only recent events related to the economic crisis in Japan (the fall in property values, lower interest rates, the deregulation of loans and changed rules combined with later marriage) have made ownership accessible to single women as well. As regards the age structure, younger participants are prevalent in the Serbian population (57.81\%), whereas the structure of the Slovenian and the Japanese populations is similar. The majority of Japanese participants are single (65.12\%), which we interpret in the light of research findings (Deutsch et al., 2005) showing that the average age of a Japanese person establishing his or her own household is close to 40 years, which is high compared to the US (29 years) or Austria (31 years). Research (Deutsch et al., 2005) also shows that this is due to their banking policy, which allows a maximum encumbrance on one's personal income of $25 \%$ and a minimum personal interest in the purchase of property of up to $20 \%$ of the property value, and to high property prices, meaning that a Japanese property buyer must pay an average of 8.5 percent of his or her entire annual income.

Considerable differences between the participants exist in terms of home-ownership. The majority of homeowners are Serbian participants (67.19\%), followed by Slovenian (53.64\%) and Japanese participants (27.91\%). We interpret this in the light of the housing ownership structure in the selected countries, which shows that, in 2010, Serbia had a little over $90 \%$ owneroccupied housing, Slovenia a little over $80 \%$ and Japan a little over $64 \%$. There is a significant difference in the percentage of participants living with their parents. A surprising $27.17 \%$ of Slovenian participants (between 20 and 40) live in a shared household with their parents compared to a slightly lower percentage of Japanese participants (20.93\%), whereas Serbian participants stand out for their extremely low percentage $(6.25 \%)$. The data also show that, based on the number of young people (25-34 years) living with their parents, Slovenia is at the very top. According to Eurostat (2012), 43.5\% of young people in Slovenia in this age group are still living at home. Thus, Slovenia is one of the top countries when it comes to the length of time young adults live with their parents. Table 1 shows that the majority of participants indicate that, when it comes to paying for housing, they use less than $30 \%$ of their income, whereas a very high percentage of Slovenians (45.73\%) and particularly Serbs $(72.40 \%)$ indicate that they don't spend anything. This can be interpreted with the finding that neither Slovenians nor Serbs are planning to purchase a new property in the near future (they are not saving); other reasons for this can also be found in the current economic crisis and the participants' economic power (currently reduced).

The fact that buyer expectations are changing along with changes in the economic situation on the property market was also established by Joseph T. Y. Wong and Eddie C. M. Hiu (2006). They discovered that buyers tend to be more optimistic when prices on the property market are increasing and more pessimistic when they are falling. As long as participants expect prices on the property market to increase, their behaviour generates higher demand (Wong \& Hiu, 2006, Sang-arun, 2013; Hoxha et al., 2014). As far as satisfaction is concerned, the highest level of satisfaction was expressed by the Slovenians and the lowest by the Serbs, with $14.32 \%$ of the latter being very unsatisfied with their current housing status. In a study conducted among US property buyers, William Rohe et al. (2001) discovered that the satisfaction of homeowners is higher than among participants living in rented housing. 
Table 2: Statistically significant differences in terms of cultural origin, age and housing status.

\begin{tabular}{|c|c|c|c|c|c|c|}
\hline Variables & & Sum of squares & $d f$ & Mean square & $F$ & $p$ \\
\hline Education & & 1.755 & 6 & 0.293 & 0.788 & 0.580 \\
\hline Gender & * & 3.431 & 6 & 0.572 & 2.634 & 0.015 \\
\hline Family status & $* * *$ & 4.731 & 6 & 0.789 & 4.231 & 0.000 \\
\hline Where you live (location) & & 6.699 & 6 & 1.117 & 1.419 & 0.204 \\
\hline Employment & & 4.121 & 6 & 0.687 & 2.017 & 0.060 \\
\hline Monthly housing expenditure & $* * *$ & 32.351 & 6 & 5.392 & 6.125 & 0.000 \\
\hline Satisfaction with housing status & $* *$ & 26.794 & 6 & 4.466 & 3.390 & 0.003 \\
\hline Maintenance costs & & 12.557 & 6 & 2.093 & 1.895 & 0.078 \\
\hline Sense of security & & 4.954 & 6 & 0.826 & 0.857 & 0.526 \\
\hline Sense of social security & & 6.688 & 6 & 1.115 & 0.950 & 0.458 \\
\hline Sense of a higher social status & & 9.064 & 6 & 1.511 & 1.516 & 0.169 \\
\hline Sense of independence & $* *$ & 17.9 & 6 & 2.983 & 2.856 & 0.009 \\
\hline Sense of self-satisfaction & & 9.56 & 6 & 1.593 & 1.413 & 0.206 \\
\hline Main sources of financing when purchasing a property & *** & 37.971 & 6 & 6.329 & 5.995 & 0.000 \\
\hline Expectation of positive regulatory measures & * & 13.563 & 6 & 2.260 & 2.248 & 0.037 \\
\hline
\end{tabular}

Notes:

* The difference is statistically significant $(p<0.05)$.

** The difference is statistically significant $(p<0.01)$.

*** The difference is statistically significant $(p<0.001)$.

Table 3: Correlations between variables in terms of cultural origin and housing status.

\begin{tabular}{lllllllll}
\hline & Gender & Family status & $\begin{array}{l}\text { Housing } \\
\text { status }\end{array}$ & $\begin{array}{l}\text { Monthly } \\
\text { expenditure }\end{array}$ & Satisfaction & $\begin{array}{l}\text { Indepen- } \\
\text { dence }\end{array}$ & $\begin{array}{l}\text { Financial } \\
\text { resources }\end{array}$ & $\begin{array}{l}\text { Regulatory } \\
\text { measures }\end{array}$ \\
\hline Gender & 1.000 & -0.075 & -0.065 & 0.080 & -0.075 & -0.180 & -0.134 & 0.069 \\
\hline Family status & -0.075 & 1.000 & -0.181 & 0.154 & 0.012 & -0.097 & -0.002 & 0.012 \\
\hline Housing status & -0.065 & -0.181 & 1.000 & -0.068 & -0.188 & 0.167 & 0.035 & 0.007 \\
\hline Monthly expenditure & 0.080 & 0.154 & -0.068 & 1.000 & -0.152 & -0.144 & 0.046 & 0.043 \\
\hline Satisfaction & -0.075 & 0.012 & -0.188 & -0.152 & 1.000 & -0.034 & -0.046 & -0.028 \\
\hline Independence & 0.180 & -0.097 & 0.167 & -0.144 & -0.034 & 1.000 & 0.050 & 0.008 \\
\hline Financial resources & -0.134 & -0.002 & 0.035 & 0.046 & -0.046 & 0.050 & 1.000 & -0.116 \\
\hline Regulatory measures & 0.069 & 0.012 & 0.007 & 0.043 & -0.028 & 0.008 & -0.116 & 1.000 \\
\hline
\end{tabular}

According to Reinout Kleinhans and Marja Elsinga (2010), there is a strong correlation between home ownership and the sense of self-satisfaction.

\section{Results and interpretation}

The results were statistically analysed using variance analysis. Variance analysis is a commonly used statistical method or statistical test in research, like a $t$-test for independent samples, although variance analysis makes it possible to compare the averages of three or more groups. The selected dependent variables are cultural origin, age and housing status according to the participants' basic demographic features (education, gender, family status, place of residence, employment, average monthly expenditure for housing, satisfaction with the current living conditions, maintenance costs) and based on their expectations for starting their own household in terms of social security, social status, sense of independence and selfsatisfaction, the expected regulatory measures to be taken by the state and the anticipated financial resources. The statistically significant differences in terms of cultural origin, age and housing status (the participant lives in private housing, in rented housing, with his or her parents or elsewhere) are shown in Table 2.

Statistically significant differences at the level $p<0.05$ can be seen in terms of gender and the question concerning the expected assistance from the state as part of its regulatory measures. Statistically significant differences at the level $p<0.01$ can be seen in terms of expressed satisfaction with the current housing conditions and the expressed sense of independence. 
Table 4: Average levels of agreement in relation to factors indicating statistically significant differences in terms of cultural origin, age and ownership of the property where the participants are currently living.

\begin{tabular}{|c|c|c|c|c|c|}
\hline Property status & Private & Market rent & Low-cost rent & With relatives & Other \\
\hline \multicolumn{6}{|l|}{ Variables } \\
\hline \multicolumn{6}{|l|}{ Gender } \\
\hline Slovenians & 1.42 & 1.59 & 1.50 & 1.24 & 1.30 \\
\hline Serbs & 1.24 & 1.27 & & 1.16 & 1.50 \\
\hline Japanese & 2.00 & 2.00 & 2.00 & 1.43 & 1.50 \\
\hline \multicolumn{6}{|l|}{ Family status } \\
\hline Slovenians & 1.48 & 1.41 & 1.36 & 1.47 & 1.41 \\
\hline Serbs & 1.43 & 1.45 & & 1.60 & 1.50 \\
\hline Japanese & 1.00 & 1.00 & 1.00 & 1.00 & 1.00 \\
\hline \multicolumn{6}{|c|}{ Monthly expenditure } \\
\hline Slovenians & 1.67 & 3.05 & 2.07 & 1.40 & 2.07 \\
\hline Serbs & 2.19 & 2.14 & & 1.00 & 1.00 \\
\hline Japanese & 1.00 & 2.25 & 2.00 & 1.43 & 2.00 \\
\hline \multicolumn{6}{|l|}{ Satisfaction } \\
\hline Slovenians & 3.92 & 3.70 & 2.86 & 3.62 & 3.07 \\
\hline Serbs & 4.03 & 3.00 & & 4.00 & 4.50 \\
\hline Japanese & 3.67 & 4.00 & 2.00 & 4.00 & 2.50 \\
\hline \multicolumn{6}{|c|}{ Sense of independence } \\
\hline Slovenians & 3.14 & 3.77 & 3.21 & 4.22 & 4.32 \\
\hline Serbs & 4.33 & 4.50 & & 4.60 & 4.25 \\
\hline Japanese & 4.33 & 3.25 & 2.00 & 4.00 & 4.00 \\
\hline \multicolumn{6}{|c|}{ Financial resources } \\
\hline Slovenians & 1.94 & 1.98 & 2.00 & 2.08 & 2.14 \\
\hline Serbs & 2.22 & 2.32 & & 1.80 & 2.75 \\
\hline Japanese & 1.33 & 1.25 & 2.00 & 1.71 & 1.50 \\
\hline \multicolumn{6}{|c|}{ The state's regulatory measures } \\
\hline Slovenians & 2.12 & 2.00 & 2.07 & 2.19 & 2.18 \\
\hline Serbs & 2.06 & 2.27 & & 1.60 & 1.75 \\
\hline Japanese & 2.33 & 1.75 & 2.00 & 2.79 & 1.50 \\
\hline
\end{tabular}

Statistically significant differences at the level $p<0.001$ can be seen in terms of the family status, the monthly expenditure for housing and the planned main resources when purchasing one's own property. It is interesting, however, that the correlations between factors according to the participants' housing status are weak, none of the absolute values being higher than 0.9 .

The strongest correlation exists between housing status and family status $(-0.181)$, the negative correlations suggesting that more single participants live in a shared household with their parents than those who are in a relationship. Another interesting fact is the negative correlation between housing status and satisfaction with the current housing conditions (-0.188), suggesting that the participants who live with their parents are more dissatisfied than those living in private or rented housing. The positive correlation between housing status and the sense of independence (0.167) was expected; it shows that participants living in a shared household with their parents express higher expectations about having a greater sense of independence in their own household (in their own rented or private housing).

Average levels of agreement in relation to factors indicating statistically significant differences in terms of cultural origin, age and housing status are shown in Table 4. Surprisingly, the results show that most of the participants living in a shared household, both in Serbia (the average level of agreement is 1.16) and Slovenia (the average level of agreement is 1.24), are female, whereas male participants predominate in Japan (the average rate of agreement is 1.43), which disagrees with earlier research findings (Takahashi \& Voss, 2000; Suzuki, 2003; Raymo \& Ono, 2004; Takada 2004; Fukuda, 2007), according to which in Japan, women typically marry at an earlier age than men, but men leave their parents' homes earlier. They 
cite education and employment as some of the reasons for this. However, more recent studies in the Japanese cultural environment (Hirayama, 2008; Yuichiro et al., 2015) show that differences between the sexes in the home-ownership rate are not surprising, because it is only events related to the economic crisis in Japan that have made ownership accessible to single women as well, which they report is due to the fall in property values, lower interest rates, the deregulation of loans and changed rules combined with later marriage. For Serbia and Slovenia, the gender gap can be interpreted based on the findings of Rudi Klanjšek (2013), who reports that, even though young men earn more than young women, regardless of their employment status, the gap is still closing, which puts Slovenia at the very bottom when it comes to the difference in earnings (belonging to the group of countries with the smallest gender pay gap). As regards the family status of participants living with their parents, the expressed level of agreement among Slovenians and Serbs is balanced, whereas single participants predominate in the Japanese population (the average level of agreement is 1.00). It is interesting that all the participants indicate an extremely low monthly expenditure for housing (less than $30 \%$ ), which is interpreted in the light of the findings of Ule and Kuhar (2003) that young people on average enjoy a fair degree of autonomy at home with their parents. Parents are supposed to be the ones trying to mitigate the consequences of the disintegration of the former universal welfare state (Kovacheva, 2006), which can explain the extremely low average level of agreement among the Serbian participants. In Slovenia, the average housing costs exceeded $30 \%$ of the available household income with $30.8 \%$ in 2005, 31.3\% in 2006 and 31.8\% in 2013 (Statistical Office of the Republic of Slovenia, 2014). In Japan, the average housing costs varied from $17.6 \%$ in 2001 to a little less than $18 \%$ in 2013 (Official Statistic of Japan, 2014). The significant intercultural difference in the monthly use of resources for funding one's own housing can be indicative of the participants' varying expectations and options for entering the home-ownership world. As regards the level of agreement of participants living with their parents for an extended period of time, everyone expresses a high level of satisfaction (the average level of agreement for the Serbs and Japanese is a high 4.0). This can be interpreted in the light of the results of Ramovš study (2013) showing that, among the inhabitants of Slovenia older than 50 , there is a prevailing opinion that the old and the young understand one another equally well. According to Lavrič (2011), young Slovenians have one of the best relationships with their parents in the European Union. Research also shows that in Slovenia, in addition to unfavourable conditions on the labour market and the duration of education, other reasons contributing to the long period of intergenerational living are mainly the relatively favourable conditions of living with one's parents (who mostly live in houses) and the resulting reluctance of young people to risk poverty in the early period of starting their own household (Lavrič, 2011).

With regard to the financial resources for buying a home in this category of participants, Slovenians express the highest level of agreement concerning financing through loans (their level of agreement is 2.08), whereas the Serbs and Japanese also count on their own financial resources (the level of agreement is 1.80 and 1.71 , respectively). Studies often show that younger Slovenian generations decide to buy a home with financial resources other than their own (Cvijanovič, 2010; Temeljotov Salaj \& Črne, 2010; Grum \& Čebular, 2015), because the banks' housing loan products have grown with the development of mortgage loans. With maturity of up to 30 years up to the age of 75 , it is possible to raise the necessary funds to buy an average home even with an average personal income. A mortgage loan may be secured with any unencumbered property located in Slovenia, even a property that is the subject of a purchase. Financial institutions take different approaches to breaking down the insurance market, particularly based on motivation for obtaining protection when it comes to loans. The German insurance company Alte Leipzinger bases its classification on the need for providing for the family, provisioning for old age, the needs of persons with above-average incomes, the needs of persons with below-average incomes, independent professions and special needs. In case of Slovenia, where the ratio between the active and the retired population amounted to $1.64: 1$ in 2010 , these studies showed a strong trend of anticipated assistance from the older generation in helping young people secure their first housing. However, a study by Boštjan Kerbler (2014) shows that bridging any structural gaps between the built environment and population ageing is of key importance. One of the main features of housing meeting the needs of an ageing society identified by the study is ensuring the appropriate accessibility of housing and essential and affordable services. In this respect, the two generations can establish a co-dependence to solve the problem. Hsuan Hsu (2006) studied how household ownership affected housing policy, discovering that one of the characteristics of Japan as an Asian country was the social phenomenon of the intergenerational transfer of title, which could explain the possible high expectations of financial assistance from relatives.

As regards the state's regulatory measures and assisting young people in gaining housing independence, the highest level of agreement was expressed by the Japanese (the average level of agreement is 2.79), whereas the lowest level of agreement was expressed by the Serbs (the average level of agreement is 1.60). Jan Rouwendal and Simonetta Longhi (2008) attribute this difference to the variable that, in psychological terms, generally reflects consumers' feelings of optimism or pessimism. Although the economic sentiment indicator in Slovenia has sta- 
bilised and recorded a slight growth in 2013 and although the construction confidence indicator is also settling down (Statistical Office of the Republic of Slovenia, 2014), that does not necessarily mean that the participants' expectations will follow this trend (Grum, 2014). The buyers' confidence in the property market is also slowly returning in Japan and the residential property market is thus expected to recover (Global Property Guide, 2015). The consumer confidence indicator (Economic and Social Research Institute, 2014) in Japan calculated based on monthly surveys showed that consumer confidence decreased consistently in 2006, 2007 and 2008 but later stabilised. The state's regulatory measures also affect the age of the individual's entry into his or her own household. Research (Deutsch et al., 2005) shows that the average age of a Japanese person entering his or her own household is close to 40 years, which is high compared to other counties. This is thought to be the result of Japan's banking policy, which allows a maximum encumbrance on one's personal income of up to $25 \%$ and a minimum personal interest in the purchase of property of up to $20 \%$ of the property value, and of high property prices. Housing accessibility is not only problematic in terms of the encumbrance of one's income with housing expenses, but it is also reflected in the supply of appropriate housing (Mandič, 2009). Households are faced with a clearly insufficient supply of housing in the low-cost sector, low availability of company housing, expensive market rental housing and high private housing prices (Mandič, 2009; Gibson, 2013). Unfavourable economic trends since 2008 have changed economic activity in all three countries under study. According to Alenka Kajzer (2009), this has had a significant impact on the labour market and has also brought about changes in pay trends. Due to the rising unemployment, Slovenia responded by strengthening its active labour market policy programmes. Two intervention laws aimed at job preservation were passed. The Partial Subsidising of Full-Time Work Act was adopted in January 2009 (Sln. Zakon o delnem subvencioniranju polnega delovnega casa, Ur. 1. RS,, no. 5/2009) and the Partial Reimbursement of Payment Compensation Act (Sln. Zakon o delnem pouračilu nadomestila plače, Ur. 1. RS,, no. 42/2009) was adopted at the end of May the same year. In 2009, the Japanese government responded to the crisis with a stimulative measure worth 173 billion US dollars, more than all the measures taken in 2008 combined (Global Property Guide, 2009). All of this affected the real gross domestic product rate. The research conducted by Wong and Hiu (2006) has produced some very interesting results. Ninety-five per cent of Japanese participants indicated that, when deciding on a property purchase, factors such as the economic situation, the interest rate and family income were important, but they almost completely ignored the question of the unemployment rate that, at the time when the survey was being carried out, was very high. Our results are therefore inconsistent with the results of the study cited by Klanjšek (2014), which showed that, compared to other post-Yugoslav countries, young Slovenians were more pessimistic about the country's future economic situation. However, the low level of agreement among Serbs (as well as Slovenians) regarding the state's regulatory measures and its assistance to young people in gaining their housing independence can be interpreted in the light of the findings of the quantitative research by Andrej Naterer (2011) suggesting that young people (generation Y) experience the situation they have found themselves in as relatively unfavourable and difficult, particularly when comparing themselves with generation $\mathrm{X}$ (or the baby boomers). Young people think that growing up was easier for the preceding generations and that it used to be a social project that provided everything they believe one needed for his or her independence: a job, a home and a pension. As a result, young people today see society as an undependable and sometimes even a treacherous partner with which a formal legal contract needs to be concluded to work together, as trust and good relations no longer suffice. Thus, parents once again become important partners for young people and, as Naterer (2011) points out, intergenerational living does not seem to be an indication of "being spoilt" or permissive parenting, but rather a form of good intergenerational collaboration.

Our research thus confirms our hypothesis that the young and the old living together as an extended family is not in itself an indicator of intergenerational symbiosis and solidarity, but rather a reflection of the wider social and cultural processes regulating the life of society as a whole and the lives of individuals.

\section{Conclusion}

Economic, social, cultural, political and demographic changes have a significant impact on traditional family, on social, structural and intergenerational relationships, which is also reflected in the increasingly current problem of shared households or young families living with their parents for longer periods. The article thus explores the structural factors and individual reasons behind young people living in a shared household with their parents for an extended period. In this context, we were analysing their wishes, purpose, manner and expectations after moving out and "going it alone". We were interested in finding out if they believe the state should implement regulatory measures to help them with this. Our hypothesis is that the young and old living together as an extended family is not in itself an indicator of intergenerational symbiosis and solidarity, but rather a reflection of wider social and cultural processes regulating the life of society as a whole and the lives of individuals. The main research tool used was the question- 
naire which we developed ourselves. The study was carried out in three different cultural environments: Slovenia, Serbia and Japan. The study was conducted among 1,006 Slovenian, 385 Serbian and 264 Japanese participants. The sample consisted of participants between 20 and 40, selected by gender, education, social and economic status, marital or family status, living environment and cultural identity.

The results show statistically significant differences based on the gender of young people living in a shared household. Female participants are prevalent in Serbia and Slovenia (the average level of agreement is 1.24), but male participants in this structure predominate in Japan (the average rate of agreement is 1.43). This points to significant demographic changes in Japanese society in the last ten years. Statistically significant differences can be seen in the question concerning the anticipated assistance from the state as part of its regulatory measures. The highest level of agreement was expressed by the Japanese (the average level of agreement is 2.79), whereas the lowest level of agreement was expressed by the Serbs (the average level of agreement is 1.60). Researchers attribute this difference to the variable that, in psychological terms, reflects consumers' feelings of optimism or pessimism. Although the economic sentiment indicator and the construction confidence indicator in Slovenia appear to be settling down, that does not necessarily mean that the participants' expectations will follow this trend. When it comes to Japan, the buyers' confidence in the property market is returning and the residential property market is also expected to recover in the near future. The consumer confidence indicator in Japan shows that consumer confidence has been increasing since 2013 . Statistically significant differences can also be seen in terms of the expressed satisfaction with the current housing conditions, the expressed sense of independence, family status, monthly expenditure for housing and the planned main resources when purchasing one's own property. In terms of the expressed level of agreement of participants living with their parents for an extended period of time, the highest level of satisfaction was expressed by the Serbs and the Japanese (the average level of agreement being a high 4.0), whereas in terms of the financial resources for buying a home, Slovenian participants express the highest level of agreement concerning financing through loans (the level of agreement is 2.08), whereas Serbian and Japanese participants are also counting on their own financial resources (the level of agreement is 1.80 and 1.71 , respectively). Hsu (2006) studied how household ownership affected the housing policy, discovering that one of the characteristics of Japan as an Asian country was the social phenomenon of the intergenerational transfer of title, which could explain the high expectations of financial assistance from relatives. However, we have established that the significant intercultural difference in the monthly use of funds for housing can be indicative of the participants' varying expectations and options to enter the home-ownership world or an independent household.

The study showed that, despite the fact that they get along relatively well, young people living in a shared household with their parents still want to "go it alone" and they expect greater help from the state, through regulatory measures and fairly distributed social assistance between the "young" and the "old" generations, to create social and housing policies that are fairer and friendlier to young families. This would reduce the pressure on the family and the potential for conflict within it, as well as the potential for conflict between the state and the family. And, as Richard Sendi (2013) points out, overcrowded housing causes, among other things, discomfort and health issues, which is why Slovenia must act quickly, taking into consideration the latest approaches to housing planning and ensuring the appropriate standards. The study also shows that the important steps in the traditional transition to adulthood appear in a slightly different order to that characteristic of older generations: first finishing school, followed by entering a stable labour market, moving away from home and only then starting one's own family. In this respect, the state should not forget about the importance of independence in relation to the country's fertility. This correlation is also confirmed by the case of Japan, where the average age of young people gaining their independence is the highest of the three cultures under study ( 40 years). Another characteristic of Japan is that it is the fastest-ageing society. Young people think that growing up was easier for older generations and that it used to be a social project that provided everything they believe one needed for his or her independence: a job, a home and a pension. As a result, young people today see society as an undependable and sometimes even a treacherous partner with which a formal legal contract needs to be concluded to work together, as trust and good relations no longer suffice. Thus, parents once again become important partners for young people and, as $\mathrm{Na}$ terer (2011) points out, intergenerational living does not seem to be an indication of "being spoilt" or permissive parenting, but rather a form of good intergenerational collaboration. Our research thus confirms our hypothesis that the young and the old living together as an extended family is not in itself an indicator of intergenerational symbiosis and solidarity, but rather a reflection of the wider social and cultural processes regulating the life of society as a whole and the lives of individuals.

\section{Bojan Grum}

European Faculty of Law, Real Estate Law and Management,

Ljubljana, Slovenia

E-mail:bgrum@siol.net

Alenka Temeljotov Salaj

HIOA - Oslo and Akershus, University College of Applied Sciences,

Oslo, Norway

E-mail: alenka-temeljotov.salaj@hioa.no 


\section{References}

Allen, J., Barlow, J., Leal, J., Maloutas, T. \& Padovani, L. (2004) Housing and welfare in southern Europe. Oxford, Blackwell Publishing. DOI: 10.1002/9780470757536

Aassve, A., lacovou, M. \& Mencarini, L. (2006) Youth poverty and transition to adulthood in Europe. Demographic Research, 15(2), pp. 21-50. DOI: 10.4054/DemRes.2006.15.2

Bianchi, S. M. \& Casper, L. M. (2000) American Families. Population Bulletin, 55(4), pp. 3-43.

Biggart, A., Bendit, R., Caruso, D., Hein, K. \& Morch, S. (2004) Families and transitions in Europe. Research report. Lisbon, Institute of Social Sciences, University of Lisbon.

Brandt, M., Haberkern, K. \& Szydlik, M. (2008) Soziale Dienste und Hilfe zwischen Generationen in Europa (Social services and help between generations in Europe). Zeitschrift für Soziologie, 37(4), pp. 301-20.

Bratina Jurkovič, N. (2014) Perception, experience and the use of public urban spaces by residents of urban neighbourhoods. Urbani izziv, 25(1), pp. 107-125. DOI: 10.5379/urbani-izziv-en-2014-25-01-003

Cvijanovic, D. (2010) Stanovanjska problematika in stanovanjska oskrba mladih - primer mestne občine Nova Gorica. Master's thesis. Nova Gorica, European Faculty of Law.

Deutsch, E., Tiwari, P. \& Moriizumi, Y. (2005) The slowdown in the timing of housing purchases in Japan in the 1990s. Journal of Housing Economics, 15(3), pp. 230-256. DOI: 10.1016/j.jhe.2006.09.007

Economic and Social Research Institute (2014) Monthly consumer confidence survey covering all of Japan. Tokyo.

Emmons, W. R. \& Noeth, B. J. (2014) Housing crash continues to overshadow young families' balance sheets. In the Balance, 7, pp. 1-6.

European Union Labour Force Survey (2013) Annual results 2012. Newport.

Eurostat (2012) Europe in figures, Eurostat yearbook 2012. Luxembourg.

Forrest, R., Kennett, P. \& Izuhara, M. (2003) Home ownership and economic change in Japan. Housing Studies, 18(3), pp. 277-293. DOI: 10.1080/02673030304241

Fukuda, S. (2007) The socio-economic status of women and marital fertility in post-war Japan: Effects of education, employment and family structure on parity transitions. The Journal of Population Studies, 40(2), pp. $79-100$.

Fulgosi, A. (1984) Faktorska analiza. Zagreb, University of Zagreb, Faculty of Arts.

Gibson, H., J. (2013) Rethinking the memorial in a Black Belt landscape: Planning, memory and identity of African Americans in Alabama. Urbani izziv, 24(1), pp. 144-159. DOI: 10.5379/urbani-izziv-en-2013-24-01-004

Global Property Guide (2015) Japan: Despite a weak economy and a shrinking population, Abenomics is pushing house prices up. Tokyo.

Global Property Guide (2009) House price falls in Japan accelerate. Tokyo.

Goetegeluk, R., Hooimeijer, P. \& Dieleman, F. (1992) The effectiveness of housing search: The role of motives for moving and housing market adjustment. Paper presented at the conference European Cities: Growth \& Decline, 13-16 April, the Hague, the Netherlands. Typescript.

Goldscheider, F. K. (1997) Recent changes in U.S. young adult living arrangements in comparative perspective. Journal of Family Issues, 18(special issue), pp. 708-724. DOI: 10.1177/019251397018006008
Grum, B. (2014) Differences in demographic characteristics of potential acquirers of real estate rights: Cases from Slovenia and Japan. Current Urban Studies, 2(2), pp. 105-115. DOI: 10.4236/cus.2014.22011

Grum, B. \& Kobal Grum, D. (2015) A model of real estate and psychological factors in decision-making to buy real estate. Urbani izziv, 26(1), pp. 82-91. DOI: 10.5379/urbani-izziv-en-2015-26-01-002

Grum, B. \& Čebular, U. (2015) When buying residential property young people expect more help from the state: Case of Slovenia. International Journal of Social Science Studies, 3(1), pp. 7-16.

Grum, B. \& Temeljotov Salaj, A. (2010a) Pričakovanja potencialnih pridobiteljev nepremičninskih pravic $v$ Republiki Sloveniji glede na njihov spol, starost, izobrazbo in zaposlenost. Geodetski vestnik, 54(3), pp. 501-516.

Grum, B. \& Temeljotov Salaj, A. (2010b) The external expectations of potential real estate buyers in Slovenia and Japan. Urbani izziv, 21(2), pp. 106-116. DOI: 10.5379/urbani-izziv-en-2010-21-02-004

Hartley, R. (1993) Young adults living at home. Australian Institute of Family Studies, 36(1), pp. 35-37.

Heath, S. (1999) Young adults and household formation in the 1990s. British Journal of Sociology of Education, 20(4), pp. 545-562. DOI: $10.1080 / 01425699995263$

Hirayama, Y. (2008) Womenss marital status and housing tenure in the context of Japan's home-owning society. Journal of Architecture and Planning, 73(1), pp. 1045-1052. DOI: 10.3130/aija.73.1045

Holdsworth, C. \& Morgan, D. (2006) Transitions in context: Leaving home, independence \& adulthood. Cambridge, Polity Press.

Hoxha, V., Dimitrovska Andreas, K. \& Temeljotov Salaj, A. (2014) Cultural factors affecting urban planners' intentions to regulate public space in Prishtina, Kosovo. Urbani izziv, 25(2), pp. 76-89. DOI: 10.5379/urbani-izziv-en-2014-25-02-001

Hsu, P. H. (2006) How the source of home ownership affect political attitudes? In: Sendi, R. \& Černič Mali, B. (eds.) Housing in an expanding Europe, pp. 1-16. Ljubljana, Urban Institute of the Republic of Slovenia.

Izahura, M. (2014) Life-course diversity, housing choices and constraints for women of the 'lost' generation in Japan. Housing Studies, 30(1), pp. 60-77. DOI: 10.1080/02673037.2014.933780

Jian, G. \& Kazunori, H. (2004) Residential environmental evaluation of local cities considering regional characteristic and personal residential preference: Case study of Saga City. Journal of Environmental Sciences, 16(1), pp. 138-144.

Jian, G. \& Kazunori, H. (2006) Research on residential lifestyles in Japanese cities from the viewpoints of residential preference, residential choice and residential satisfaction. Landscape and Urban Planning, 78(3), pp. 165-178. DOI: 10.1016/j.landurbplan.2005.07.004

Jolanki, O. (2015) Elderly parents' need for help and adult childrenss moving decisions. Journal of Housing for the Elderly, 29(1-2), pp. 77-91. DOI: 10.1080/02763893.2015.989763

Kajzer, A. (2009) Odziv trga dela na recesijo v Sloveniji. IB Revija, $43(3-4)$, pp. $69-76$

Keats, D.M. (2000) Interviewing, a practical guide for students and professionals. Buckingham, Open University Press.

Kerbler, B. (2014) An innovative built environment form for dwellings for the elderly. METU Journal of the Faculty of Architecture, 31(1), pp. 119-137. DOI: 10.4305/metu.jfa.2014.1.6

Klanjšek, R. (2014) Bivalne razmere in socialno-ekonomski položaj mladine. In: Center za raziskovanje postjugoslovanskih družb Mari- 
bor (ed.) Mladina 2013: življenje v času deziluzij, tveganja in prekarnosti, pp. 4-9. Maribor.

Kleinhans, R. \& Elsinga, M. (2010) ‘Buy your home and feel in control` does home ownership achieve the empowerment of former tenants of social housing? International Journal of Housing Policy, 10(1), pp. 41-61.

Klinc, R., Turk, Ž. \& Dolenc, M. (2010) Raziskava o rabi informacijskokomunikacijskih tehnologij v slovenski gradbeni industriji. Gradbeni vestnik, 59(11), pp. 269-276.

Korpi, W. (2000) Faces of inequality: Gender, class, and patterns of inequalities in different types of welfare states. Social Politics: International Studies in Gender State and Society, 7(2), pp. 127-191.

DOI: 10.1093/sp/7.2.127

Kovacheva, S. (2006) Youth transitions and family support in a transforming social context: Reflections from the New Member States. In: Lutz, W., Richter, R. \& Wilson. C. (eds.) The new generations of Europeans: Demography and families in the enlarged European Union, pp. 145-176. London, Sterling, Earthscan.

Kuhar, M. (2012) Podaljšano sobivanje staršev in mladih odraslih. Socialno delo, 51(6), pp. 205-218.

Kuhar, M. (2013) Analiza dejavnikov podaljšanega sobivanja staršev in otrok v Sloveniji. Teorija in praksa, 50(5-6), pp. 5-6.

Lavrič, M. \& Klanjšek, R. (2013) Stanovanjske in bivalne razmere mladih. In: Center za raziskovanje postjugoslovanskih družb Maribor (ed.) Mladina 2013: življenje v času deziluzij, tveganja in prekarnosti, pp. 282-305. Maribor.

Lavrič, M. (2011) Ključne ugotovitve študije Mladina 2010. In: Lavrič, M. (ed.) Mladina 2010 - Družbeni profil mladih v Sloveniji, pp. 587-590. Ljubljana, Ministry of Schools and Sport, Slovenia Office for Youth \& Založba Aristej.

Lobe, B. (2006) Mixing qualitative and quantitative methods in the environment of new information-communication technologies. Ljubljana, Faculty of Social Science.

Mandič, S. (2007) Odhod v prvo samostojno stanovanje: primerjalna analiza med državami Evropske unije. Družboslovne razprave, 13(54), pp. 7-24.

Mandič, S. (2009) Stanovanjske razmere mladih. In: Rakar, T. \& Boljka, U. (eds.) Med otroštvom in odraslostjo, analiza položaja mladih v Sloveniji 2009, pp. 77-93. Ljubljana, Slovenia Office for Youth and the Slovenia Institute for Social Welfare.

Mandič, S. \& Filipovič Hrast, M. (2015) Alternatives to social housing: Applicants' views of various policy options. Urbani izziv, 26(1), pp. 6981. DOI: 10.5379/urbani-izziv-en-2015-26-01-001

Mulder, C. (2006) Housing and population: A two-sided relationship. Housing in an expanding Europe; theory, policy, participation and implementation. Ljubljana, Urban Institute of the Republic of Slovenia.

Naterer, A. (2011) Zeitgeist mladih. In: Lavrič, M. (ed.) Mladina 2010 Družbeni profil mladih v Sloveniji, pp. 579-586. Ljubljana, Ministry of Schools and Sport, Slovenia Office for Youth \& Založba Aristej.

National Institute of Population and Social Security Research (2008) Latest Demographic Statistics 2008. Tokyo.

Official Statistic of Japan (2014) Yearly average of monthly disbursements per household. Tokyo.

Pompe, A. \& Temeljotov Salaj, A. (2014) Qualitative criteria of urbanism and brands: A comparative analysis. Urbani izziv, 25(1), pp. 74-92. DOI: 10.5379/urban-izziv-en-2014-25-01-001

Raymo, J. M. (2003) Premarital living arrangements and the transi- tion to first marriage in Japan. Journal of Marriage and Family, 65(2), pp. 302-315. DOI: 10.1111/j.1741-3737.2003.00302.x

Raymo, J. M. \& Ono, H. (2004) Coresidence with parents, the "comforts of home," and the transition to marriage among Japanese women. Madison, University of Wisconsin, Center for Demography and Ecology.

Ramovš, K. (2013) Medgeneracijsko sožitje in solidarnost. Kakovostna starost, 16(4), pp. 3-33.

Rohe, W. M., Zandth, S. \& McCarthy, G. (2001) The social benefits and costs of homeownership: A critical assessment of the research. Cambridge, Joint Center for Housing Studies of Harvard University.

Rouwendal, J. \& Longhi, S. (2008) The effect of consumer's expectations in a booming housing market: Space-time pattern in the Netherlands, 1999-2000. Housing Studies, 23(3), pp. 291-317. DOI: $10.1080 / 02673030801893107$

Sang-arun, N. (2013) Development of regional growth centres and impact on regional growth: A case study of Thailand's Northeastern region. Urbani izziv, 24(1), pp. 160-171. DOI: 10.5379/urbani-izziven-2013-24-01-005

Sendi, R. (2013) The low housing standard in Slovenia: Low purchasing power as an eternal excuse. Urbani izziv, 24(1), pp. 107-124. DOI: 10.5379/urbani-izziv-en-2013-24-01-002

Statistical Office of the Republic of Slovenia (2014) Slovenia in figures 2013. Ljubljana.

Stropnik, N. \& Šircel, V. (2008) Slovenia: Generous family policy without evidence of any fertility impact. Demographic research, 19(7), pp. 10191058. DOI: 10.4054/DemRes.2008.19.26

Suzuki, T. (2003) Leaving home in Japan: Its trends, gender differences, and determinants. Journal of Population Problems, 59(1), pp. 1-18.

Suzuki, T. (2007) Recent developments in household formation in Japan. Journal of Population Problems, 63(1), pp. 1-13.

Takada, S. (2004) Living arrangements of single Japanese women: Are Japanese parents altruistic? Journal of Population Studies, 34(1), pp. 1-11.

Takahashi, H. \& Voss, J. (2000) Parasite singles: A uniquely Japanese phenomenon? JEl Report 31A, pp. 1-12.

Temeljotov Salaj, A. \& Črne, J. (2010) Tveganje posameznikov in družinske skupnosti ob najemu hipotekarnega kredita. Dignitas, 4546(1), pp. 193-214.

Tomanović, S. \& Ignjatović, S., (2006) Attitudes on transition to adulthood among young people in Serbia. Sociologija, 48(1), pp. 56-72. DOI: 10.2298/SOC0601055T

Ule, M. \& Kuhar, M. (2003) Mladi, družina, starševstvo. Ljubljana, Fakulteta za družbene vede.

van Ommerren, J., Rietveld, P. \& Nijkamp, P. (2000) Job mobility, residential mobility and commuting. Annals of Regional Sciences, 34(2), pp. 213-232. DOI: 10.1007/s001689900004

Vogel, J. (2002) European welfare regimes and the transition to adulthood. Social Indicators Research, 59(3), pp. 275-299. DOI: 10.1023/A:1019627604669

Waldron, V. R., Gitelson, R., Kelley, D. \& Regalado, J. (2005) Losing and building supportive relationships in later life: A four-year study of migrants to a planned retirement community. Journal of Housing for the Elderly, 19(2), pp. 5-25. DOI: 10.1300/J081v19n02_02

Walker A. (2006) Active ageing in employment: Its meaning and potential. Asia Pacific Review, 13(1), pp. 78-93. DOI: $10.1080 / 13439000600697621$ 
Walonic, D. S. (2007) Survival statistic. Bloomington, StatPac, Inc.

Wong, J. T. Y. \& Hui, E. C. M. (2006) Research notes: Power

of expectations. Property Management, 24(5), pp. 496-506.

DOI: 10.1108/02637470610710547

Yau, Y. (2015) The value of building safety: A hedonic price approach. Urbani izziv, 26(1), pp. 92-104.

DOI: 10.5379/urbani-izziv-en-2015-26-01-003

Yuichiro, l., Ichiro, M. \& Yasutaka, T. (2015) Data analysis for monitoring Japan's real estate market. Tokyo. 